BOGUSŁAW SKOWRONEK

Instytut Filologii Polskiej

Uniwersytet Pedagogiczny w Krakowie
Images

vol. XXVII/no. 36

Poznań 2020

ISSN 1731-450X

\title{
Warstwa werbalna ścieżki dźwiękowej jako element współbudowania przestrzeni $w$ filmie
}

\begin{abstract}
AвSTRACT. Skowronek Bogusław, Warstwa werbalna ścieżki dźwiękowej jako element współbudowania przestrzeni $w$ filmie [The verbal layer of the soundtrack as an element of co-construction of space in film]. "Images" vol. XXVII, no. 36. Poznań 2020. Adam Mickiewicz University Press. Pp. 215-223. ISSN 1731-450X. DOI 10.14746/i.2020.36.14.

The article presents the most typical ways of co-building various types of film space through the verbal layer of the soundtrack: inside the frame and outside of it, diegetic and non-diegetic, and narrative and non-narrative. In order to discuss linguistic ways of co-creating space, the author used the tenets of mediolinguistics and the ideas of the textual image of the world and the linguistic image of the world.

KEYWORDs: film space, linguistic film discourse, verbal layer of soundtrack, textual image of the world, linguistic image of the world, Woody Allen, Quentin Tarantino, Stanley Kubrick, Marek Koterski, Jan Jakub Kolski, Władysław Pasikowski, Wojciech Smarzowski
\end{abstract}

Każda sztuka kształtuje przestrzeń w sposób sobie właściwy, proponując specyficzne ujęcie parametrów określających przestrzeń rzeczywistą

Alicja Helman, Andrzej Pitrus, Podstawy wiedzy o filmie

Jedną z głównych tez językoznawstwa kognitywnego oraz lingwistyki kulturowej jest założenie, iż podstawa systemu konceptualnego każdego człowieka opiera się na fundamencie doświadczeń percepcyjnych, motorycznych, somatycznych, potem także społecznych i kulturowych. Ludzka myśl, wiedza i konceptualizacje rzeczywistości są więc „ucieleśnione”, czyli określone przez możliwości poznania dane przez ciało. Najprostsze doświadczenia stoją u podstaw tak zwanych schematów wyobrażeniowych (pojęciowych, prekonceptualnych), dzięki którym każda osoba może orientować się w świecie. Tworzą się one we wczesnym dzieciństwie i dotyczą przede wszystkim relacji przestrzennych, jako podstawowych dla egzystencji człowieka, bo umożliwiających reprezentację obiektów znajdujących się w pewnym otoczeniu. Pojęcia złożone kształtują się natomiast poprzez nałożenie podstawowych schematów wyobrażeniowych na dziedziny bardziej abstrakcyjne. Zasadniczym mechanizmem umożliwiającym takie nakładanie są procesy metaforyzacji. Ważny w nich udział biorą również rozmaite dziedziny sztuki - w tym film, wykorzystujący określone dla danego czasu konwencje obrazowania.

W ujęciu kognitywno-kulturowym dzieło kinematograficzne (w prototypowym rozumieniu) można zdefiniować jako „przedstawie- 
nie za pomocą ruchomego obrazu jakiejś historii”[1]. Owo „przedstawienie" - podstawowy komponent semantyczny tej definicji - zawsze odnosi się do kategorii przestrzeni (a raczej rozmaitych sposobów jej przejawiania się na ekranie). Obraz filmowy „musi” być reprezentacją „Czegos” - jakiejś przestrzeni. Semantyka „przedstawienia” odzwierciedla zatem prymarną funkcję dzieła filmowego - budowania reprezentacji rzeczywistości. Odnosi się tym samym do kategorii przestrzeni. W niniejszym tekście kategorię tę rozumiem jednak nie tylko jako specyficzny wyznacznik obrazu filmowego, ile jako najważniejszy czynnik określający przestrzeń opowiadania, którą jest układ wszystkich elementów tworzących świat przedstawiony w filmie. Pamiętać trzeba, że przestrzeń opowiadania jest mentalnym konstruktem, który widz tworzy w trakcie odbioru filmu na podstawie płynących z ekranu danych obrazowych oraz dźwiękowych - w tym także słownych (werbalnych).

Charakterystyka wszystkich semantycznych aspektów przestrzeni opowiadania, poszczególnych jej typów oraz estetyczno-formalnych wyznaczników wykracza poza wąskie ramy tego artykułu. W tekście koncentruję się jedynie na warstwie werbalnej ścieżki dźwiękowej jako paśmie znaczeniowym współkreującym różne wymiary filmowej przestrzeni. Głównym obszarem mojego zainteresowania jest „przestrzeń diegetyczna”, zależna od rozwoju świata przedstawionego, w którym toczą się filmowe zdarzenia, oraz „przestrzeń narracyjna”, składnik szerzej rozumianej strategii opowiadania, organizującej przede wszystkim relacje podmiot - przestrzeń[2]. Co ważne, dla odbiorcy „orientacja $\mathrm{w}$ przestrzeni filmowej to przede wszystkim orientacja w przestrzeni diegetycznej lub ze względu na tę przestrzeń" [3]. Z powyższą typologią André Gardiesa w dużej mierze łączy się klasyfikacja przestrzeni Davida Bordwella. Z klas przez niego wyróżnionych zajmuję się w artykule „przestrzenią scenograficzną”, czyli przestrzenią fikcyjnego świata filmowego, szczególnie zaś tym jej wymiarem, który nazywany jest „przestrzenią dźwiękową”. Koncepcję „przestrzeni scenograficznej” Bordwella (z jej pasmem akustycznym) w praktyce badawczej można utożsamiać z koncepcją „przestrzeni diegetycznej” Gardiesa[4]. Tak też czynię w niniejszym tekście.

Nie jest dla nikogo zaskoczeniem, iż w refleksji filmoznawczej głównym pasmem znaczeń, które ma budować przestrzeń, jest warstwa obrazu. Najbardziej typowymi środkami wyrazu temu służącymi są techniki zdjęciowe, praca kamery, montaż oraz inscenizacja. Bodźce wizualne stanowią po prostu naturalniejsze i wiarygodniejsze źródło informacji niż pozostałe zmysły, w tym słuch. Zjawisko to w psychologii określa się jako „dominację wzrokową" [5]. Znajduje ono również odzwierciedlenie w jednym z podstawowych schematów poznawczych

[1] B. Skowronek, Konceptualizacje filmu i jego oglądania w jezzyku młodzieży. Studium kognitywno-kulturowe, Kraków 2007, s. 52.

[2] E. Ostrowska, Przestrzeń filmowa, Kraków 2000, s. $16-17$.
[3] A. Helman, A. Pitrus, Podstawy wiedzy o filmie, Gdańsk 2008, s. 67.

[4] E. Ostrowska, op.cit., s. 25-26.

[5] Ibidem, s. 31. 
człowieka - schemacie wyobrażeniowym: „widzieć to wiedzieć”. Oczywiście, system percepcyjny człowieka nieprzerwanie zestawia, porównuje i uspójnia informacje płynące $z$ rozmaitych receptorów. Tak właśnie dzieje się w odbiorze filmu. Widz $\mathrm{z}$ reguły bez problemu tworzy spójne reprezentacje umysłowe dwóch warstw: obrazu i dźwięku, nawet jeśli w niektórych momentach między nimi występuje jakaś niekoherencja. Przestrzeń w filmie należy więc zawsze traktować - powtórzę wyrażoną wcześniej tezę - jako konstrukt poznawczy, sumę uspójnionych konceptualizacji odbiorcy, dokonywanych na podstawie danych formalnych filmu: wizualnych, dźwiękowych i językowych.

Nie negując zatem dominacji obrazowych wyznaczników przestrzeni, chcę zaakcentować fakt, iż ścieżka akustyczna - a w nim przede wszystkim warstwa werbalna - również bardzo aktywnie (współ)tworzy przestrzeń każdego filmu. Co więcej, ścieżka dźwiękowa jest prawie zawsze „kalibrowana na dialog” - ma on bowiem priorytet wobec innych rodzajów dźwięku. Warstwa werbalna stanowi jeden z najważniejszych przekaźników informacji fabularnej. Pomaga widzowi w rozumieniu i interpretacji wydarzeń. Umożliwia rozpoznawanie i rozumienie sytuacji w diegezie - wreszcie indywidualizuje i charakteryzuje bohaterów, daje wgląd w psychologiczną przyczynowość fabuły. Dzięki temu określa się horyzont poinformowania widza (tu szczególnie ważna jest rola charakteryzująca i lokatywna poszczególnych wypowiedzi), autentyzm przedstawionego świata, złożoność motywacji psychologicznej protagonistów. Personalizowanie mówienia - tworzenia osoby poprzez ciało i głos - to bardzo ważny element filmowej narracji[6]. Słowo w filmie jako zorganizowany zestaw werbalnych wskazówek, skłaniających odbiorców do wyciągania odpowiednich wniosków i gromadzenia informacji o opowiadanej historii, buduje wyraźnie dramaturgię filmu[7]. Dzięki wypowiedziom bohaterów narracja może się rozwijać i w finale prowadzić do zamierzonego celu. Główną rolą sfery verbum w filmie jest tworzenie medialnego - w tym przypadku filmowego - obrazu świata, czyli budowania przekonania widza o autentyzmie świata przedstawionego wraz z uzasadnieniem jego logiki.

Koncepcja medialnych obrazów świata stanowi bardzo ważną część założeń mediolingwistyki[8], transdyscyplinarnej dziedziny badawczej, łączącej językoznawstwo kulturowe i kognitywne oraz filmoznawstwo i medioznawstwo, której celem jest badanie warstwy werbalnej poszczególnych przekazów (tekstów) medialnych, niezależnie od technologii ich powstania i kontekstów funkcjonowania. Koncepcja mediolingwistyki zakłada, iż wszystkie media (w tym oczywiście także film) niedeterministycznie wpływają na konceptualizowanie przez odbiorców zjawisk rzeczywistości, rozumienie ich i wartościowanie, podobnie jak i na ogólne konstrukcje języka oraz całościowe zasady

[6] I. Sowińska, Dźwięki i obrazy. O słuchaniu filmów, Katowice 2001, s. 86.

[7] J. Ostaszewski, Historia narracji filmowej, Kraków 2018, s. 87 .
[8] Por. B. Skowronek, Mediolingwistyka. Wprowadzenie, Kraków 2013. 
komunikacji. I co najważniejsze: wszystkie media (film, prasa, radio, telewizja) generują własne medialne obrazy świata na podstawie przyjętego przez nadawców specyficznego obrazowania rzeczywistości i elementów wspólnej dla danego społeczeństwa bazy kulturowej. Wymiar werbalny ścieżki dźwiękowej każdego zdarzenia wizualnego, które spełnia prototypowe warunki filmowości[9], można nazwać językowym dyskursem filmowym - na podobieństwo innych językowych dyskursów medialnych: prasowego, radiowego, telewizyjnego oraz internetowego[10].

Główny „mechanizm semiotyczny” językowego dyskursu filmowego (tak jak i pozostałych językowych dyskursów medialnych) opiera się na kognitywno-językowych działaniach o charakterze kreatywnym. Polegają one na dyskursywnym modyfikowaniu/reinterpretowaniu/profilowaniu istniejących i utrwalonych społecznie językowych obrazów świata[11] i tworzeniu na ich podstawie określonych wizji rzeczywistości, jej wizualno-werbalnych wariantów, czyli (wspomnianych już) filmowych obrazów świata. Ich językową realizacją jest konkretny w dziele tekstowy obraz świata, czyli funkcjonujące w filmie pasmo językowe (poszczególne wypowiedzi). Każdy jednostkowy film (rozumiany tu jako tekst) ma zatem swój własny, odrębny od innych filmów, tekstowy obraz świata. Stanowi akceptację (lub odrzucenie) jego składowych, ich ukonkretnienie, rozwinięcie lub uszczegółowienie - zgodnie z założoną przez twórców autorską strategią.

W kontekście funkcjonowania przestrzeni filmowej wypowiedzi postaci stanowią zwerbalizowany, „ujęzykowiony” spójny konstrukt, współkreujący istnienie i funkcjonowanie składników świata przedstawionego, współtworzący ich związki oraz wzajemne usytuowanie i proporcje. I tak jak konkretne miejsce (lokacja) stanowi wizualny "tekst” przestrzeni filmowej, tak również konkretne użycie języka, poszczególne wypowiedzi są werbalnym „tekstem” przestrzeni filmowej[12]. Pamiętać jednak trzeba, że oryginalne tekstowe obrazy świata (słowa użyte w konkretnych filmach), choć będące aktem kreacji, nie mogą „uciec” od znaczeń językowego obrazu świata utrwalonych w danej kulturze. Kreatywność językowa w danym filmie (oryginalność i/lub nietypowość warstwy werbalnej) nigdy nie może się odbywać kosztem jego komunikatywności i/lub odbiorczej akceptacji.

Po tych ustaleniach definicyjnych i terminologicznych pora na przedstawienie głównych, moim zdaniem, sposobów współbudowania przez sferę verbum różnych typów przestrzeni. Na początku należy zaznaczy, że język w filmie realizuje się w swoistym kontinuum tekstowych realizacji (może nawet rozpięciu) między odpowiedniością, równowagą wobec obrazu (semiotyczną relewancją) a innowacyjnością,

[9] Por. K. Klejsa, A film-like thing, czyli o tym, jak zjawiska filmopochodne utrudniaja odpowiedź na pytanie: „co to jest film?”, [w:] Kino po kinie. Film w kulturze uczestnictwa, red. A. Gwóźdź, Warszawa 2010.
[10] Por. Język w mediach. Antologia, red. M. Kita, I. Loewe, Katowice 2014.

[11] Por. J. Bartmiński, Językowe podstawy obrazu świata. Lublin 2006.

[12] E. Ostrowska, op.cit., s. 34. 
„nadmiarowością”, kreacyjnym naddatkiem wobec obrazu (semiotyczną redundancją). Warstwa werbalna współbuduje zatem przestrzeń filmową w bardzo różny sposób, funkcjonując w rozmaitych wariantach i formach. Wzajemne relacje pasma werbalnego i pasma wizualnego w konkretnym filmie z jednej strony są efektem pracy twórców (co oczywiste), ale z drugiej - ich wyodrębnienie i opis stanowi też efekt działań interpretacyjnych. Dla wielu widzów dialogi w filmie są jakby „przezroczyste”, traktowane wręcz jako znaturalizowane tło akustyczne percypowanej fabuły.

Słowa jako werbalny tekst przestrzeni filmowej odnoszą się najczęściej do trzech jej głównych typów: 1) przestrzeni wewnątrzkadrowej/przestrzeni pozakadrowej, 2) przestrzeni diegetycznej/przestrzeni pozadiegetycznej oraz 3) przestrzeni znarratywizowanej/przestrzeni nieznarratywizowanej. Wszystkie wymienione tu typy (wraz z określającymi je środkami wyrazu) należy widzieć jako semiotyczną całość, choć w konkretnych filmach relacje między poszczególnymi rodzajami przestrzeni mogą wyglądać inaczej, przyjęte zabiegi słowne odpowiednio bowiem profilują, modyfikują lub inaczej kreują właściwy typ filmowej przestrzeni.

Najbardziej typowym sposobem współbudowania przestrzeni przez język, równocześnie najbardziej skonwencjonalizowanym i wpisanym w podstawowy tryb narracji, jest model, w którym istnieje równowaga wszystkich pasm semiotycznych: obrazu, dźwięku i mowy. Najczęściej stosowanym zabiegiem w kinematografii, wręcz prototypowym rozwiązaniem formalnym, jest też sytuacja, w której mówiące postaci w zdecydowanej większości czasu ekranowego funkcjonują w obrębie kadru, tym samym bytują eksplicytnie w świecie opowiadania. Jest to równocześnie realizacja wzorcowego, modelowego typu przestrzeni filmowej, jaką jest przestrzeń wewnątrzkadrowa. Ale spotyka się również takie użycia języka, które kierują uwagę odbiorców na przestrzeń pozakadrową. Może to być głos spoza kadru (voice over), rozumiany jako głos sytuujący się „ponad” światem przedstawionym, należący do narratora albo do postaci z diegezy, ale niesłyszanej przez innych bohaterów. Dziś można je spotkać na przykład $\mathrm{w}$ filmach Woody'ego Allena. Innym typem budowania przestrzeni pozakadrowej jest mowa zza kadru (voice off), w której źródło dźwięków i słów znajduje się poza kadrem, ale w przestrzeni opowiadania $\mathrm{i}$ jest dostępne percepcyjnie postaciom $\mathrm{z}$ diegezy[13]. Tę pozakadrową przestrzeń tworzą więc mentalnie sami widzowie, rekonstruując i integrując dane językowe oraz budując na ich podstawie koherentny świat przedstawiony. Przykładami filmów, w których strona werbalna tworzy przede wszystkim tę przestrzeń pozakadrową, mogą być dwa tytuły: Locke (reż. Steven Knight, Anglia 2013) oraz Winni (reż. Gustaw Möller, Dania 2018). W obydwu tych dziełach bohaterowie rozmawiają głównie przez telefon w jednej lokacji, słowa niewidocznych dla widzów interlokutorów wraz z wypowiedziami postaci funk[13] J. Ostaszewski, op.cit. s. 28. 
cjonującymi w ramie ekranu budują ostatecznie przestrzeń zmienną, opalizującą, niejednoznaczną - istniejącą głównie poza kadrem, którą tworzą sami widzowie. Jest to chwyt interesujący właśnie dlatego, że wybitnie aktywizuje odbiorcę, który poprzez odpowiednią dystrybucję informacji słownej indywidualnie buduje dramaturgię historii i tym samym przestrzeń opowiadania.

Przestrzeń wewnątrzkadrowa wraz z przestrzenią pozakadrową (istniejącą jednak w opowiadaniu) składają się na przestrzeń diegetyczną, świat filmowej opowieści. To również wzorzec prototypowej przestrzeni w filmie, przestrzeni fabuły konstruowanej w trakcie odbioru przez widza. Właśnie ją najmocniej współtworzy - obok środków wizualnych - pasmo językowe danego filmu, czyli zawarty w nim tekstowy obraz świata. Bardzo wielu reżyserów jest mocno „wyczulonych na słowo". Wszyscy oni potrafią nader przekonująco wykreować za pomocą języka specyficzne dla siebie tekstowe obrazy świata. Wystarczy tu przywołać choćby Woody`ego Allena, Quentina Tarantino, Stanleya Kubricka czy z polskich twórców Stanisława Bareję, Marka Koterskiego, Jana Jakuba Kolskiego, Władysława Pasikowskiego i Wojciecha Smarzowskiego[14]. W obrazach tych twórców warstwa werbalna bardzo wyraziście współtworzy przestrzeń diegetyczną. Jednak, mówiąc o przestrzeni diegetycznej i indywidualnie tworzonych tekstowych obrazach świata, nie można pomijać przestrzeni pozadiegetycznej, przestrzeni symbolicznej, nadbudowanej nad diegezą. Przestrzeń pozadiegatyczna została przez Elżbietę Ostrowską nazwana nawet „przestrzenią niemożliwą”, dlatego że „nie może być całkowicie uzasadniona jako istniejąca w obszarze diegesis"[15]. Tworzą ją znaczenia kulturowe zawarte w użytych w filmie konstrukcjach werbalnych, związane z zakodowanymi w danej społeczności konceptualizacjami zjawisk świata, ich rozumieniem, wartościowaniem itp. Są to właśnie te znaczenia, które tkwią $\mathrm{w}$ utrwalonym społecznie, skonwencjonalizowanym językowym obrazie świata. Ów obraz świata to sensy języka „ukryte”, a raczej nadbudowane nad klasycznym poziomem informacyjności monologów czy dialogów postaci filmowych. Wszystkie wypowiedzi użyte w filmie nie tylko bowiem informują o świecie przedstawionym, ale też odsłaniają ugruntowany społecznie obraz rzeczywistości, czyli zbiorową świadomość utrwaloną w języku, obowiązujące stereotypy, przekonania, wartości społeczne, normy moralne czy wzorce konceptualizacji świata. Język w filmie stanowi zawsze swoisty „sejsmograf” lingwistyczno-kulturowy, precyzyjnie ukazujący społeczne nastroje i emocje, rejestrujący ponadjednostkowe wzorce mówienia i myślenia, odsłaniający kody kulturowe oraz matryce ideologiczne danej społeczności. Dzięki temu warstwa werbalna filmów precyzyjnie ujawnia zarówno językowe strategie autorskie twórców, jak też tkwiące głębiej

[14] Por. M. Miławska-Ratajczak, Dialog w roli głównej. Polszczyzna we współczesnym kinie na przykładzie wybranych autorów, Kraków 2018.
[15] E. Ostrowska, op.cit., s. 29. 
kulturowe motywacje oraz wpojone językowe wzorce konceptualizacji rzeczywistości.

Tworzenie konkretnego tekstowego obrazu świata, funkcjonującego w dziele na poziomie przestrzeni diegetycznej, jest „słyszalne” eksplicytnie. To ważny aspekt definiujący słowo w tym typie przestrzeni. Natomiast językowy obraz świata przestrzeni pozadiegetycznej ujawnia się niejako implicytnie, jest bowiem pozornie „niewidoczną”, bo znaturalizowaną i „przezroczystą” dla członków danej kultury podstawową bazą - swoistą macierzą językową. I co bardzo ważne, jest ona dostępna dopiero poprzez działania interpretacyjne świadomego widza (lub badacza). Trzeba pewnej kompetencji lingwistyczno-kognitywno-kulturowej, aby głos postaci filmowych ujawniał nie tylko autorski koncept dialogisty, tekstowy obraz świata, ale również odsłaniał językowy obraz świata, charakteryzujący właśnie przestrzeń pozadiegatyczną. Przykładem takiego podejścia mogą być analizy określonych kategorii dyskursywnych i/lub stereotypów typowych dla danej grupy społecznej. Tak mediolingwistycznie sprofilowane badania przestrzeni pozadiegetycznej były już prowadzone. Analizowałem w ten sposób między innymi językowy obraz kobiet i mężczyzn oraz stereotyp Rosji i Rosjan, funkcjonujące w polskim kinie popularnym[16].

Pamiętać jednak trzeba, że dwie podstawowe przestrzenie funkcjonujące w filmie: diegetyczna i pozadiegetyczna, istnieją nie tyle obok siebie, ile łącznie, tworząc zawsze semiotyczną całość. To aktywność percepcyjna i kognitywna widza oraz jego wiedza zewnętrzna wobec świata ekranowej fikcji umożliwia korelację danych, zewnątrz- i wewnątrztekstowych. To ważna cecha charakterystyczna języka w filmie: istnienie relacji między eksplicytnym, tekstowym poziomem języka, współtworzącym przestrzeń diegetyczną a pozadiegetyczną przestrzenią symboliczną, kreowaną przez implicytny poziom „ukrytych” znaczeń języka, nienależący bezpośrednio do przestrzeni opowiadania, ale ciągle istniejący i trwały, bo utrwalony kulturowo i społecznie. I zawsze gotowy do „wydobycia” przez interpretatora - widza i/lub badacza.

Z omówionymi wyżej typami przestrzeni i współtworzącymi je werbalnymi wykładnikami zespolone są dwa kolejne rodzaje przestrzeni filmowej: znarratywizowana oraz nieznarratywizowana[17]. W przestrzeni znarratywizowanej pasmo werbalne wraz z innymi środkami formalnymi musi być silnie podporządkowane historii opowiadanej przez film, stać się znaturalizowanym, niewyróżniającym się składnikiem narracji. Przede wszystkim winno zaspokajać niezbędne i konieczne potrzeby informacyjne widzów. Głównym zadaniem używanego przez postaci języka ma być wtedy poświadczanie autentyzmu i logiki świata przedstawionego (i to $\mathrm{z}$ reguły bezpośrednio ograniczonego do

[16] Por. B. Skowronek, Językowy obraz Rosji i Rosjan w kinie polskim po 1990 roku. Rekonesans, „Historyka. Studia Metodologiczne" 2011, t. XLI; J. Paździo, B. Skowronek, O dwóch Karolach i ich haremiankach. Lingwistyczny i (pop)kulturowy portret kobiecości i mę- skości w filmach „Och, Karol”, [w:] Oblicza płci. Język. Kultura. Edukacja, red. M. Karwatowska, J. Szpyra-Kozłowska, Lublin 2012.

[17] E. Ostrowska, op.cit., s. 36. 
miejsca akcji). W przypadku przestrzeni znarratywizowanej mamy zatem do czynienia z pełną integracją (relewancją) wszystkich składowych formalnych (w tym języka). Można więc powiedzieć, że jest to pasmo konwencjonalnego użycia języka, budowania głównie przestrzeni wewnątrzkadrowej i diegetycznej, charakterystyczne dla klasycznego kina hollywoodzkiego, kina realizującego założenia tak zwanego „stylu zerowego" [18]. Zdecydowanie ciekawiej (pod względem artystycznym) wyglądają zadania języka w współtworzeniu przestrzeni nieznarratywizowanej. W tym typie przestrzeni filmowej użyte środki wyrazu są niezależne (redundantne) wobec linii fabularnej dzieła. Elementy ją tworzące - tu oczywiście także język postaci - „zakłócają” klasyczną logikę i przebieg opowiadania, rozbijają jej realistyczne motywacje, utrudniają zbudowanie koherentnej reprezentacji świata przedstawionego przez widzów. Tu mieszczą się więc wszystkie kreacyjne elementy (w tym werbalne), będące nietypowymi rozwiązaniami, pozostającymi często w luźnym związku z przebiegiem historii.

Sfera verbum przestrzeni nieznarratywizowanej, podobnie jak i inne typowe dla niej środki formalne, charakteryzuje się więc dużą (choć stopniowalną) autonomią względem logiki opowiadania. Słowa tworzące tę przestrzeń pojawiają się w tych filmach, w których dialogi ewidentnie „słychać”, a język stanowi semiotyczny „naddatek”. Pasmo werbalne staje się wtedy jeśli nie „nadrzędne” w diegezie, to zdecydowanie wyróżniające się - „osobne”, bo semantycznie istotne. Decydują oczywiście o tym rozmaite uwarunkowania, stąd też można spotkać się z ogromnym zróżnicowaniem konkretnych realizacji formalnych. $\mathrm{Z}$ sytuacją słownej przestrzeni nieznarratywizowanej mamy do czynienia w przypadku niektórych gatunków (na przykład mumblecore, sophisticated comedy, odmiany slow cinema), specyficznych strategii narracyjnych (na przykład w kinie postfabularnym, w którym liczy się nie opowieść i słowo, ale samo pokazywanie atrakcji[19] i w niektórych obrazach „mind-game films”, kwestionujących w przestrzeni opowiadaniu zarówno pozycję narratora, jak i widza[20]) oraz w przypadku dzieł, w których użyty specyficzny język staje się głównym i dominującym chwytem artystycznym, przejawem wyrazistej autorskiej strategii w tworzeniu ścieżki werbalnej (na przykład w filmach Kieł Yorgosa Lantimosa [Grecja 2009], Plemię Mirosława Słaboszpyckiego [Ukraina 2014] czy Dzień świra Marka Koterskiego [Polska, 2002]). W tym ostatnim obrazie wypowiedzi głównego bohatera Adasia Miauczyńskiego - nagromadzenie wulgaryzmów, obecność neologizmów i form nowatorskich (od fonetycznych, po składniowe), repetycja wyrazów, trudności morfologiczne w wymowie, językowe aluzje intertekstualne, wreszcie radykalna kolokwializacja - pokazują celową nadorganizację

[18] Por. M. Przylipiak, Kino stylu zerowego. Dwadzieścia lat później, Sopot 2016.

[19] Por. B. Szczekała, Kino postfabularne i karnawał atrakcji, „EKRANy” 2015, nr 3-4.
[20] Por. idem, Mind-game films. Gry z narracja i widzem, Łódź 2018.

[21] M. Miławska-Ratajczak, op.cit. s. 127. 
płaszczyzny werbalnej, jej nieprzeźroczystość w przebiegu narracji oraz celową sztuczność[21]. W przypadku tego typu dzieł można nawet mówić o personalnej organizacji (dystrybucji) przestrzeni werbalnej - czyli sytuacji, w której twórca obdarza postać własną odrębną przestrzenią idiomatycznego języka, autonomiczną względem porządku samego opowiadania.

Skrótowo omówione w niniejszym artykule sposoby współbudowania przestrzeni filmowej przez warstwę werbalną ścieżki dźwiękowej należy, rzecz jasna, traktować jako pewien rekonesans, próbę zarysowania w perspektywie mediolingwistycznej zarówno pewnych koncepcji teoretycznych, jak i praktycznych propozycji analitycznych. Należy podkreślić, że wobec bogactwa przejawów współczesnej kinematografii przedstawienie wyczerpującego katalogu wszystkich stosowanych (i możliwych) rozwiązań formalnych w zakresie współistnienia warstwy obrazu i warstwy języka jawi się jako rzecz trudna do wykonania i zdecydowanie przekraczająca ramy jednego artykułu.

Bartmiński J., Językowe podstawy obrazu świata, Lublin 2006

B I B L I O G R A F I A

Helman A., Pitrus A., Podstawy wiedzy o filmie, Gdańsk 2008

Język w mediach. Antologia, red. M. Kita, I. Loewe, Katowice 2014

Klejsa K., A film-like thing, czyli o tym, jak zjawiska filmopochodne utrudniaja odpowiedź na pytanie: „co to jest film?”, [w:] Kino po kinie. Film w kulturze uczestnictwa, red. A. Gwóźdź, Warszawa 2010

Miławska-Ratajczak M., Dialog w roli głównej. Polszczyzna we współczesnym kinie na przykładzie wybranych autorów, Kraków 2018

Ostaszewski J., Historia narracji filmowej, Kraków 2018

Ostrowska E., Przestrzeń filmowa, Kraków 2000

Pajdzińska A., Ryszard T., Językowy obraz świata - konwencja i kreacja, „Pamiętnik Literacki” 1996, r. LXXXVII, z. 4

Paździo J., Skowronek B., O dwóch Karolach $i$ ich haremiankach. Lingwistyczny $i$ (pop)kulturowy portret kobiecości i męskości w filmach „Och, Karol”, [w:] Oblicza płci. Język. Kultura. Edukacja, red. M. Karwatowska, J. Szpyra-Kozłowska, Lublin 2012

Przylipiak M., Kino stylu zerowego. Dwadzieścia lat później, Sopot 2016

Skowronek B., Językowy obraz Rosji i Rosjan w kinie polskim po 1990 roku. Rekonesans, „Historyka. Studia Metodologiczne” 2011, t. XLI

Skowronek B., Konceptualizacje filmu i jego oglądania w języku młodzieży. Studium kognitywno-kulturowe, Kraków 2007

Skowronek B., Mediolingwistyka. Wprowadzenie, Kraków 2013

Sowińska I., Dźwięki i obrazy. O słuchaniu filmów, Katowice 2001

Szczekała B., Kino postfabularne i karnawał atrakcji, „EKRANy” 2015, nr 3-4

Szczekała B., Mind-game films. Gry z narracja i widzem, Łódź 2018

Locke, reż. Steven Knight (Anglia 2013)

F I L M O G R A F I A

Winni, reż. Gustaw Möller (Dania 2018)

Kieł, reż. Yorgos Lantimos (Grecja 2009)

Plemię, reż. Mirosław Słaboszpycki (Ukraina 2014)

Dzień świra reż. Marek Koterski (Polska 2002) 